Int. Arch. Allergy 1954;5:I-IV

\title{
Contents, Vol. 5, 1954
}

International Archives

of

Allergy and Applied Immunology

Incorporating the Proceedings of National Allergy Societies

A. v. ALBERTINI, Zurich

D. BOVET, Roma

C. J. C. BRITTON, London

T. BROMAN, Göteborg

G. DAHLBERG, Uppsala

H. A. E. v. DISHOECK, Leiden

G. DOHLMAN, Lund

J. DUCHAINE, Bruxelles

G. ESTRADA DE LA RIVA, Havana

F. J. FARRERONS-CO, Barcelona

P. FORMIJNE, Amsterdam

W. FREY, Bern

A. GIGON, Basel

F. GRÖER, Krakow

A. GRUMBACH, Zurich

M. J. GUTMANN, Jerusalem

B. HALPERN, Paris

CONTRIBUTING EDITORS:

K. HANSEN, Lübeck B.

W. JADASSOHN, Geneve A.

E. A. KABAT, New York B.

W. KAUFMAN, Bridgeport, Conn. C.

W. KREMER, Amsterdam M.

G. LÖFSTRÖM, Uppsala B.

W. LUTZ, Basel G.

E. H. MAJER, Wien J.

J. R. MARRACK, Cambridge P.

R. MEIER, Basel B.

J. A. MORETTI, MontevideoE.

A. OLIVEIRA-LIMA, Rio de Janeiro L.

D. ORDMAN, Johannesburg H.

W. PAGEL, London U.

M. M. PESHKIN, New York A.

J. R. PRAKKEN, AmsterdamA. 
W. J. QUARLES van UFFORD,

G.

Utrecht

RATNER, New York R. RICH, Baltimore, Md. M. RILEY, Sidney RIMINGTON, London

ROCHA E SILVA, São Paulo ROSE, Montreal RUIZ MORENO, Buenos Aires RUNNSTRÖM,

Stockholm SANGIORGI, Milano SCHICK, New York SCHMIDT, Marburg a. d. Lahn

SCHWARTZ, Washington, D. C. SELYE, Montreal SERAFINI, Firenze STOLL, Basel

TISELIUS, Uppsala L. WALDBOTT, Detroit, Mich.

E. A. Brown

Boston, Mass.

D. Harley

London

EDITORS-IN-CHIEF:

P. Kallós W. Löffler

Helsingborg Zurich

F. W. Wittich

Minneapolis, Minn.

Vol. 5

1954

BASEL (Schweiz) S. KARGER NEW YORK

Index

Amrein, H. P., vide Burckhardt, W.

Biozzi, G., vide Ovary, Z.

Brendler, R., vide Brenn, $H^{*}$

Brenn, H. und R. Brendler, Allergie gegen Antiallergica . Suppl. 34

Bueno, P., Studies on the Pathogenesis of Experimental Tuberculous Skin

Lesions 289

Burckhardt, W. und H. P. Amrein, Sensibilisierungen mit Thioglycerin

und Thioglykolsäure am Meerschweinchen Suppl. 57

Chase, M. W·, Experimental Sensitization with Particular Reference to

Picryl Chloride 163

Diamant, M. und P. Kallós, Intrabronchiale Cortisonbehandlung von schweren Asthmafällen 283

Ehrlich, P., Über Partialfunktionen der Zelle. Nobel-Vortrag ... 67

Fischer, E., Zur Frage der Übertragung des ekzem-allergischen Prinzipes durch Lymphocyten Suppl. 73

Fleming, A., A Test to Show the Relative Toxicity of a Chemical to Bac teria and to Human Leucocytes $\quad 160$

Flückiger, J., vide Hoigné, R.

Flückiger, P., vide Hoigné, R. 
Friebel, $\mathrm{H} \cdot$, Über das experimentelle allergische Asthma der Meerschweinchen und seine Beziehungen zum Asthma des Menschen .. . 377, 401

Gell, P. G. H. and I. T. Hinde, Observations on the Histology of the Arthus Reaction and its Relation to Other Known Types of Skin Hypersensitivity 23

Hahn, F., G. Mülke und G. Schmitz-Bocklenberg, Zur Frage der pharmakologischen Beeinflußbarkeit der Masugi-Nephritis mit besonderer Beriicksichtigung der Antihistaminica 224

Heuser, G., vide Selye, H.

Hinde, I. T., vide Gell, P. G. H.

Hoigné, R·, P. Flückiger, J. Flückiger und H. Storck, Thrombocytentest

«in vitro» bei medikamentösen Allergien Suppl. 50

Hugues, J·, vide Lecomte, J.

Inderbitzin, Th., Kutanallergische und allgemein anaphylaktische Erscheinungen nach wiederholter ACTH-Applikation .... Suppl. 68

- und H. Meyer, Beitrag zur Frage der Insulinallergie . . . Suppl. 62

Junet, R., Urticaire géante à $\Gamma$ A. C. T. H Suppl. 46

Kallós, P., vide Diamant, M.

Kaufman, W., Some Aspects of Psychotherapy in Allergic Practice 209

Lecomte, J. et J. Hugues, Action inhibitrice de Théparine sur le phénomène d'Arthus $\quad 367$

Lottenbach, K., vide Noelpp, B.

Marrack, J· R·, Forty Years of Immunochemistry 192

Maunsell, K., Concentration of Airborne Spores in Dwellings Under Nor

mal Conditions and Under Repair 373

Metaxas, M. N. und M. Metaxas-Bühler, Studien über passive TuberkulinallergieSuppl. 56

Metaxas-Bühler, M., vide Metaxas, M. N.

Meyer, $\mathrm{H} \cdot$, vide Inderbitzin, $\mathrm{Th}$.

Miescher, G., Diskussion Suppl. 57, 61, 76, 94

Mozer, J.-J., Cortisone et maladies infectieuses Suppl. 3

Mühlberger, F., Zur Morphologie der eosinophilen Cholecystitis und die

Frage ihrer allergischen Genese $\quad 434$

Mülke, G., vide Hahn, $\Gamma$.

Musso, E., A propos de reactions urticariennes dans la névrodermite dissé-

minée. Poussières de Geneve - Poussières de St. Moritz . . . Suppl. 53

Noelpp, B., I. Noelpp-Eschenhagen und K. Lottenbach, Das Verhalten der elastischen

Lungenspannung und des Gewebs-Deformationswider-standes bei der experimentellen

asthmatischen Dyspnoe .... 245

Noelpp-Eschenhagen, I., vide Noelpp, B.

Ovary, Z. and G. Biozzi, Passive Sensitization of the Skin of the Guinea Pig

with Human Antibody241

Pepys, J·, The Effect of Nitrogen Mustard on the Tuberculin Reaction . 233

Pope, C. G., Diphtheria Toxin and Antitoxin. A Short Review of Progress

Since the Work of Ehrlich 115

Rosenow, G·, Paul Ehrlichs Bedeutung für die Hämatologie . . . 
Saurer, A., Diskussion $\quad$ Suppl. 45, 94

Saxer, E., Weitere Untersuchungen über die tuberkulöse Reinfektion und die Tuberkulinallergie beim Rind Suppl. 30

Schlossberger, H., Entwicklung der Allergielehre in der Serologie . . 261

Schmitz-Bocklenberg, G., vide Hahn, F.

Schnitzer, A., Über Nebenwirkungen des Irgapyrins 47

- $\quad$ Histaminmechanismus und allergische Reaktion .... Suppl. 87

Selye, H. and G. Heuser, Experimental Studies Concerning the Role of

Hormonal, Vascular and Nervous Factors in the Regulation of the "Ana-

phylactoid Reaction" of the Rat 52

Sexton, W. A., The Role of the Organic Chemist in Chemotherapy . . 141

Storck, H., Allergische Reaktionen auf Blumenpollen der Compositen Suppl.

- vide Hoigné, R. Stühmer, A., Paul Ehrlich, Persönlichkeit und Werk in der Sicht des Dermatologen 87

Wiedemann, E., Recent Developments in the Technique of Electrophoresis

Wodehouse, R. P., Standardization and Antigenic Analysis of Pollen Ex

tracts by Gel Diffusion

337

- $\quad$ Antigenic Analysis by Gel Diffusion. 1. Ragweed Pollen .... 425

Work, T. S., The Work of Paul Ehrlich and His Position in the History of

Medical Research 98

To the Memory of Paul Ehrlich, March 14, 1854 - August 20, 1915 65-206

Memoranda

Björklund, B., Qualitative Analysis of Gel Precipitates with the Aid of

Chemical Colour Reactions 293

Gispen, R., Mass Inoculations with the Aid of One-Way Valves for Multiple

Injections from one Syringe 452

Laborie, R., vide Ukrainczyk-Laborie, F.

Munch, H·, Isonicotinsäurehydrazid-Kontaktdermatitis 298

Ukrainczyk-Laborie, F. et R. Laborie, A propos d'un cas de névrodermite

et sa sérologie 305

Reference List of British Proprietary Anti-Histaminics .... 449

Obituary — Nécrologie - Nekrolog

Dr. Willem Kremer $\dagger \quad 457$

Proceedings - Sociétés - Gesellschaftsberichte

British Association of Allergists 397

Collegium Internationale Allergologicum. First Symposium 336

Netherlands Association for Allergists 63, 312, 458

Schweizerische Allergie-Gesellschaft/Société Suisse d'AUergie Suppl. 1

News Items - Nouvelles - Nachrichten .... 63, 207, 333, 398

Book Reviews - Livres nouveaux - Buchbesprechungen 335, 400

Alle Rechte, insbesondere das der Übersetzung in fremde Sprachen, vorbehalten.

Ohne ausdrückliche Genehmigung des Verlages ist es auch nicht gestattet, diesen Band oder

Teile daraus

auf photomechanischem Wege (Photokopie, Mikrokopie) zu vervielfältigen.

Printed in Switzerland

Cliches: Steiner \& Cie., Basel 
Buchdruckerei zur Neuen Aargauer Zeitung Aarau 